\title{
SLAVES TO ROME: THE RHETORIC OF MASTERY IN TITUS' SPEECH TO THE JEWS (BELLUM JUDAICUM 6.328-50)
}

\author{
Myles Lavan
}

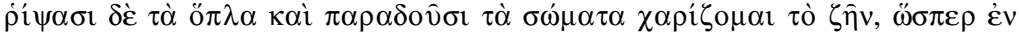

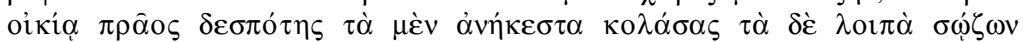
$\dot{\varepsilon} \mu \alpha v \tau \hat{\omega}$.
\end{abstract}

$(B J 6.350)$

Those who discard their weapons and surrender their persons, I will let live. Like a lenient master in a household, I will punish the incorrigible but preserve the rest for myself.

So ends Titus' address to the embattled defenders of Jerusalem in the sixth book of Josephus' Jewish War (6.328-50). It is the most substantial instance of communication between Romans and Jews in the work. ${ }^{1}$ Titus compares himself to the master of a household and the Jewish rebels to his slaves. Is this how we expect a Roman to describe empire? If not, what does it mean for our understanding of the politics of Josephus' history? The question is particularly acute given that this is not just any Roman but Titus himself: heir apparent and, if we believe Josephus, the man who read and approved this historical account. ${ }^{2}$ It is thus surprising that, while the speeches of Jewish advocates of submission to Rome such as Agrippa II (2.345-401) and Josephus himself (5.362-419) have long fascinated readers, Titus' speech has received little or no attention. Remarkably, it is not mentioned in any of three recent collections of essays on Josephus. ${ }^{3}$ This paper aims to highlight the rhetorical choices that Josephus has made in constructing this voice for Titus-particularly his self-presentation as master-and the interpretive questions these raise for his readers. It should go without saying that the relationship of this text to anything that Titus may have said during the siege is highly problematic. (Potentially more significant, but unfortunately no less speculative, is the question of how it might relate to any speech recorded in the commentaries of Vespasian and Titus that Josephus appears to have used as a source. ${ }^{4}$ ) What we have is a Josephan composition that is embedded in the broader narrative of the Jewish War.

This paper will demonstrate that our response to Titus' speech largely depends on the literary and cultural context in which we choose to read it. Much work has been done recently on the question of what audience Josephus was writing for. ${ }^{5}$ In his preface he aspires to reach all the inhabitants of the Roman empire (1.3), both Greeks and Romans $(1.16,1.6)$. Various deductions can also be made about the ideal reader implied by the text. The Jewish War presents itself as a work of Greek historiography, but it is also replete with material that can only be understood by those familiar with Jewish issues and debates. It has therefore become conventional to observe that at different points the Jewish 


\section{MYLES LAVAN}

War appears to have Roman, provincial and specifically Jewish audiences in mind - that this is a text that seeks both to explain the Romans to the Jews and to justify the Jews to the wider Greco-Roman world. Of course Josephus may never have gained the widespread readership he aspired to. Steve Mason has argued that the Jewish War is unlikely to have circulated much beyond the city of Rome. ${ }^{6}$ But even Rome alone would provide a very diverse set of readers, ranging from those steeped in Jewish culture and discourse to those who knew little about it (apart from what they learned from the work itself). Josephus himself claims that it was read both by notable members of the Jewish diaspora at Rome such as Agrippa II and by prominent Romans including Titus and Vespasian. ${ }^{7}$ This paper takes as axiomatic the inevitable heterogeneity of the audiences that the Jewish War was written for and consumed by. It explores some of the consequences of the different expectations and cultural codes against which the Jewish War must have been-and indeed continues to beread. It does so by the heuristic device of contrasting two reading strategies, one of which approaches the Jewish War as a work in the Greek historiographical tradition, while the other reads it with an eye to its Jewish context. I will show that these 'Greek' and 'Jewish' readings suggest very different responses to Titus' rhetoric.

\section{Slaves and masters}

Because so little has been written on the subject, it is worth beginning with an overview of the speech and its strategies of persuasion. Titus speaks at a parley requested by the Jewish leaders Simon and John after the destruction of the temple has forced the rebels to retreat to the upper town. His speech is an appeal for the Jews to see reason (as Titus would have it) and surrender. It opens (6.328-29) and ends (347-50) by accusing the Jews of self-destructive fury. Its main body presents a narrative of Roman-Jewish relations that repeatedly contrasts Roman generosity and restraint with Jewish ingratitude, madness and depravity. This is a speech that claims the moral high-ground for Rome. It

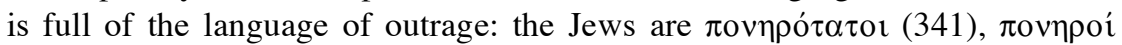

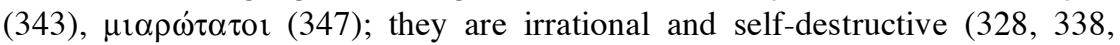
$349)$; they have no sense of shame $(338,341)$. Titus compares them to vicious reptiles that cannot be tamed (336) and an injury that will not heal (337). ${ }^{8}$ Their

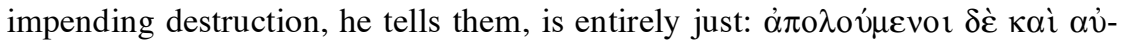

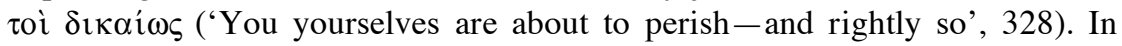
contrast, Roman rule is idealised not only for its moderation- $\phi \imath \lambda \alpha v \theta \rho \omega \pi i \alpha$ $(333,340)$ and $\pi \rho \alpha o ́$ tns $(340,350)$ are key words in this speech - but also for the material benefits it brings to its subjects (335-36). So far, this is precisely the self-serving rhetoric one might expect of a Roman speaker. But other aspects of Titus' rhetoric are more surprising, particularly the language in which he describes submission to Rome: 


\section{SLAVES TO ROME}

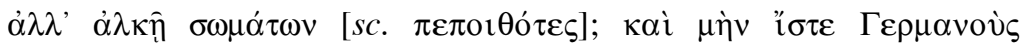

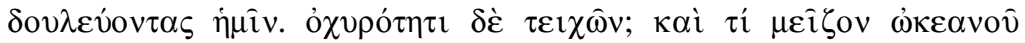

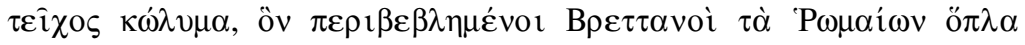

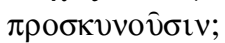

(BJ 6.331)

Was it to your physical strength [that you trusted]? But you know that even the Germans are our slaves. To the strength of your walls? Yet what obstacle is greater than the wall of Ocean which surrounds the Britons? And they too kneel before Roman arms.

I will return later to the striking trope of making proskynesis to Roman arms. For now, I want to consider the representation of the Germans as Rome's slaves

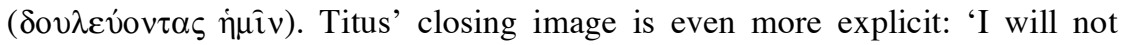
compete with you in madness. Those who discard their weapons and surrender their persons, I will let live. Like a lenient master in a household (

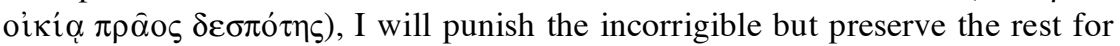

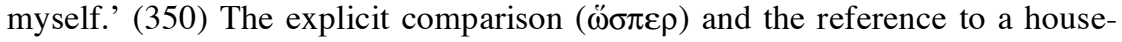
hold (oikía) leave no doubt that this is an allusion to the domestic reality of slavery. It is important to see that Titus casts himself in the role of master in an attempt to convince the Jews that he is willing to show mercy. Although he will punish the incorrigible, he has no interest in needless violence to the rest. Keeping them alive is in his own best interest. In the logic of Titus' rhetoric, the Jews should be reassured that Titus is thinking like a master because it means that he will apply a master's rationality to the question of their life and welfare.

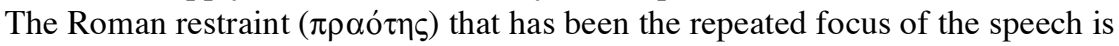
ultimately revealed as a master's virtue.

The yoking of claims of Roman beneficence with the rhetoric of mastery in Titus' speech is surprising for many reasons, not least because the idea of slavery to Rome is a recurring feature of Zealot rhetoric as it is represented in the Jewish War. Josephus gives little rhetorical space to his political opponents, granting them almost no speeches in direct speech (the exceptions being a short speech by Simon the Idumaean and the two speeches of Eleazer at Masada). ${ }^{9}$ However, he does regularly paraphrase their arguments in indirect speech and these paraphrases are dominated by emotive appeals to liberty and condemnations of Roman rule as enslavement. ${ }^{10}$ Some other speakers such as Ananus and Jesus challenge the rebels' language of slavery. ${ }^{11}$ Titus embraces it.

However, the appeal to the paradigm of slavery to justify submission to Rome is not peculiar to Titus. It can also be found in the rhetoric of two Jewish proponents of accommodation with Rome: Agrippa II and Josephus himself. Delivered on the eve of war, Agrippa II's attempt to dissuade his rebellious countrymen from revolt (2.345-405) is probably the best known speech of the Jewish War. ${ }^{12}$ Far from rejecting rebel claims that Roman rule is enslavement, Josephus' Agrippa repeatedly uses the language of slavery to describe submis- 


\section{MYLES LAVAN}

sion to Rome. He tells his audience that all other peoples have reconciled themselves to slavery to Rome: the Athenians are slaves to the Romans ( $\delta$ ov $\lambda \varepsilon v$ -

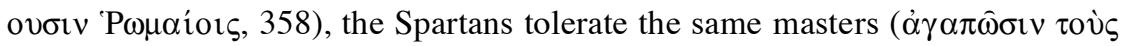

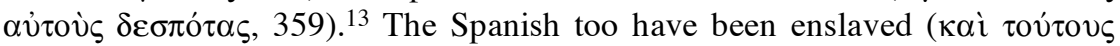

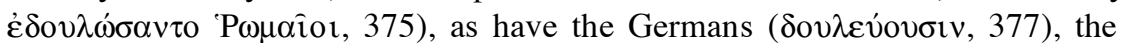

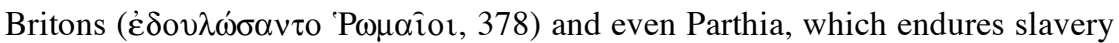

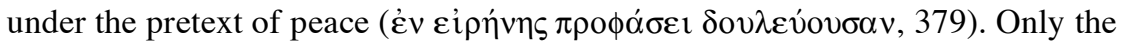

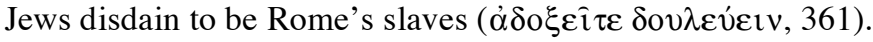

But the idea of Jewish enslavement that the rebels use to incite revolt is twisted by Agrippa into an argument for acquiescence:

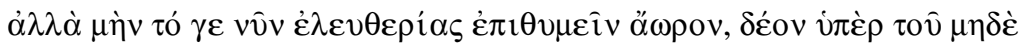

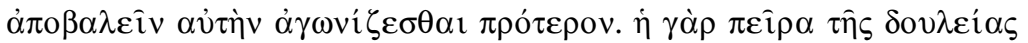

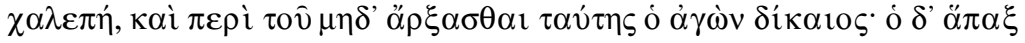

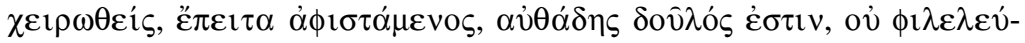

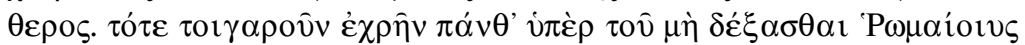

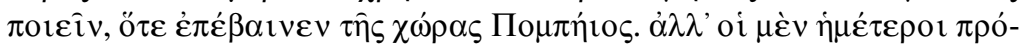

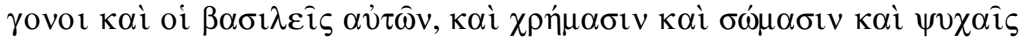

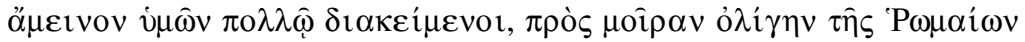

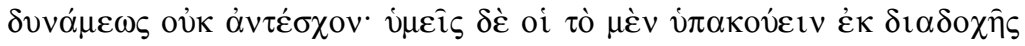

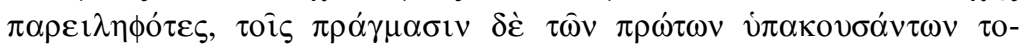

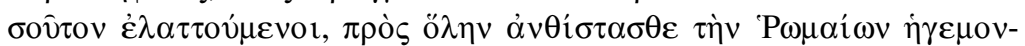
i $\alpha v$;

(BJ 2.355-57)

As for your present passion for liberty, it comes too late. The proper time for struggle is earlier - to hold on to one's liberty. Slavery is a harsh condition and the struggle not to become a slave is a just one. But the man who has once been mastered and later rebels is a recalcitrant slave, not a lover of liberty. Thus it was when Pompey came to this country that you should have made every effort not to admit the Romans. But our ancestors and their kings, who much outclassed you in wealth, body and spirit, could not withstand a small fraction of Rome's power. Will you, who have successively inherited submission, who are materially so much weaker than those who first yielded-will you stand against the whole Roman empire?

Agrippa draws a stark distinction between a free man fighting to avoid enslavement and a slave struggling against his condition. He concedes that the life of a slave is harsh ( $\dot{\eta} \gamma \dot{\alpha} \rho \pi \varepsilon \hat{i} \rho \alpha \tau \hat{\eta} \varsigma \delta o v \lambda \varepsilon i \alpha \varsigma \chi \alpha \lambda \varepsilon \pi \hat{\eta})$ and that it is just ( $\delta$ í $\alpha 10 \varsigma$ ) to resist enslavement. But the moment of enslavement changes everything: for a slave to struggle against his condition is merely contemptible - the act of a recalcitrant slave ( $\alpha \dot{v} \theta \alpha \dot{\delta} \eta \varsigma \delta o v \hat{\lambda o \varsigma}$ ) not a lover of liberty ( $\left.\phi \imath \lambda \varepsilon \lambda \varepsilon v \dot{\theta} \theta \varepsilon \varsigma_{\varsigma}\right)$. By implication servile defiance is not even just ( $\left.\delta \dot{i} \kappa \alpha \iota \varsigma\right)$. 


\section{SLAVES TO ROME}

This is a master's ethic and Agrippa appeals to it in order to suggest that for the Jews the time for legitimate resistance is long past. He adds that revolt is doomed to failure. Because they have been born to submission, the Jews of the present have even less chance of withstanding Roman power than their ancestors did. The experience of domination saps body and soul. In short, Agrippa is appealing to his audience as masters. He seeks to mobilise their contempt for troublesome slaves in order to represent the attempt to shake off the shackles of Roman rule as a contemptible and ultimately futile transgression of the moral order.

Agrippa's rhetoric is closely echoed by the later speech in Josephus' own voice in which he tries to persuade the defenders of Jerusalem to surrender (5.362-419). ${ }^{14}$ The first half of the speech repeats almost all of Agrippa's arguments. (The second breaks new ground with a biblical excursus showing that the Jews have always been defeated when they resorted to arms rather than trusting in God.) Like Agrippa, Josephus condemns revolt as a form of servile resistance:

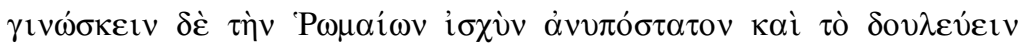

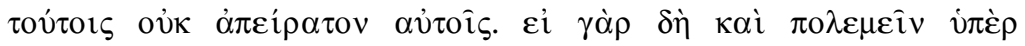

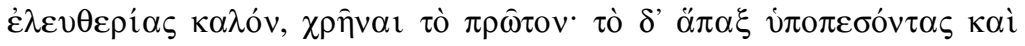

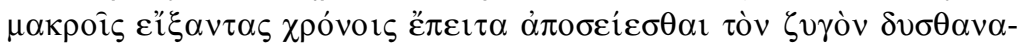

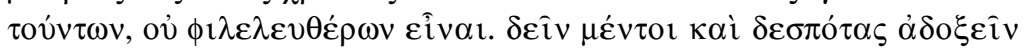

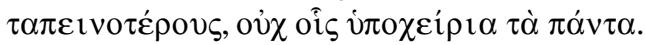

(BJ 5.364-66)

They knew [he said] that Rome's strength could not be withstood and that it was no new experience for them to be their slaves. Even if it was noble to wage war for freedom, this had to be done at the beginning. But for those who had once bent the knee and had long submitted, to struggle against the yoke was the act of die-hards, not lovers of liberty. It was certainly right to despise lesser men as masters, but not those who ruled the whole world.

Josephus draws the same distinction between the resistance of a free man and that of a slave. To fight against enslavement is admirable ( $\kappa \alpha \lambda$ óv); to struggle against the yoke of slavery once imposed is not. Like Agrippa, Josephus denies that revolt against Rome is the act of $\phi 1 \lambda \varepsilon \lambda \varepsilon v \dot{\theta} \theta \varepsilon \rho \mathrm{t}$. The rebels are merely diehards $(\delta v \sigma \theta \alpha v \alpha \tau o \hat{v} v \varepsilon \varsigma)$. A case might be made for reading $\delta v \sigma \theta \alpha v \alpha \tau \omega \dot{v} \tau \omega v$ (from $\delta v \sigma \theta \alpha v \alpha \tau \alpha \dot{ } \omega$, 'long for death') rather than $\delta v \sigma \theta \alpha \nu \alpha \tau o v v \tau \omega v$ (from $\delta v \sigma \theta \alpha v \alpha \tau \varepsilon$ ' $\omega$, 'struggle against death'). The latter makes slightly better sense here ('men with a death wish') and would constitute another link with the speech of Titus, who also accuses the Jews of a death wish ( $\delta v \sigma \theta \alpha v \alpha \tau \hat{\alpha} v$, 6.349). ${ }^{15}$ But I will not press the distinction here. Both verbs point to the futility 


\section{MYLES LAVAN}

of the Jewish attempt to shake off the yoke. Like all servile resistance, it is doomed to failure.

Josephus also urges his countrymen to realise that slavery to Rome need not be cause for shame. Conceding that the Jews might well consider it beneath

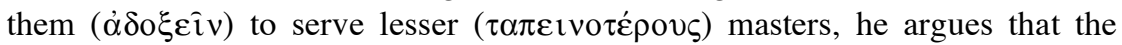
Romans with their world-spanning empire are not to be so despised. Agrippa had made the same point in his speech, claiming that the Jews were the only people to 'think it contemptible to be the slave of those who rule the world'

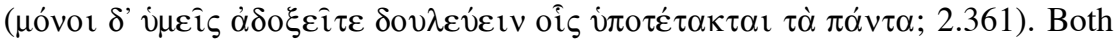
Agrippa and Josephus imply some forms of slavery are not necessarily to be despised ( $\dot{\alpha} \delta \circ \xi \varepsilon \hat{\imath} v)$ - that slavery need not be shaming so long as one's master is prestigious enough. This is a claim that must have had some force given the power and status achieved by some slaves of powerful men (notably the emperor's slaves) in the Roman world. ${ }^{16}$

It should by now be obvious that Titus' rhetoric of mastery is anticipated by the earlier speeches of Agrippa and Josephus. The question of how the various speakers of the Jewish War relate to one another has too often been neglected in the analysis of individual speeches. Steve Mason, for example, has suggested that the speech of Agrippa is ironically undermined by a series of what he sees as factual errors in the speech. ${ }^{17}$ But he never addresses the fact that so much of Agrippa's rhetoric is echoed and reaffirmed by the later speech in the voice of Josephus himself. Tessa Rajak describes the speeches of Agrippa and Josephus as 'the voice of realists', expressing the ambivalent but pragmatic attitudes of provincial elites to Roman power. ${ }^{18}$ Yet Josephus does not create as much rhetorical distance between the Jewish voices of Agrippa and himself and the Roman voice of Titus as Rajak's formulation suggests. Conversely, any reading of the speech of Titus must engage with the extent to which its rhetoric is anticipated by earlier Jewish speeches. I will return to this below.

It should also be clear that Titus' speech is embedded in a wider debate about freedom and slavery. ${ }^{19}$ The rhetoric of the rebels is blunt: submission is enslavement and therefore hateful. But the response of at least some of their opponents - both Jews and Romans - is more subtle. They find ways to turn the slavery analogy into an argument for submission to Rome: suggesting that the very powerful can make worthy masters, mobilising contempt for the futility of servile resistance, and arguing that rational masters will not be needlessly cruel to their slaves. It is true that none of these speakers succeeds in convincing his audience. Agrippa, Josephus and Titus all fail to dissuade the Jews from further conflict. But we should not take this as an internal critique of the persuasiveness of their arguments. As Jonathan Price argues in this volume, the failure of rhetoric is central to Josephus' narrative: a series of futile appeals to reason illustrates the triumph of irrational forces over logos that Josephus sees at the root of the revolt. These speeches are supposed to seem convincing; their failure to persuade is symptomatic of the breakdown of rational communication. This ought to be true of their arguments from slavery as well. Counter-intuitive 


\section{SLAVES TO ROME}

as they may seem to modern readers, these appeals to mastery as a paradigm of legitimate authority must have had potential resonance in a society of masters. ${ }^{20}$ Nevertheless, they are not necessarily the arguments we expect to find in political speeches in a work of Greek historiography. This raises the issue of expectations, which is an acute problem for the Jewish War. How we respond to Titus' rhetoric of mastery depends on how we choose to read Josephus' work.

\section{2. 'Greek' and 'Jewish' frames}

A reader approaching the Jewish War as a work of Greek historiography cannot but read Titus' speech against the conventions of imperial self-representation in that tradition and particularly in Thucydides and Polybius, Josephus' most important literary models for the War. ${ }^{21}$ Although Athenian rule is quite frequently described as enslavement in Thucydides, the metaphor is almost entirely limited to the rhetoric of Athens' enemies. ${ }^{22}$ The only time an Athenian speaker uses the language of slavery is to an Athenian audience. ${ }^{23}$ Nowhere in Thucydides do Athenians represent themselves as masters when speaking to their allies or subjects - not even in the Melian dialogue, Thucydides' famous representation of the rhetoric of power stripped bare of any attempt to justify itself. Although the Melians repeatedly describe subjection to Athens as slavery, the Athenians themselves prefer other terms (i்íкоor, $\dot{\alpha} \rho-$ $\chi$ ó $\mu \varepsilon v o 1)$ for the status of their subjects, despite the otherwise unabashed realism of their rhetoric. ${ }^{24}$ In Polybius too, it is primarily Rome's enemies who accuse Rome of enslavement. ${ }^{25}$ But the language of mastery is also incorporated into some Roman speeches, notably that of Publius Scipio on the eve of the battle on the Ticinus in 218 BCE. Scipio tells his troops that they have nothing to fear since the Carthaginians are their tributaries and therefore all but their slaves:

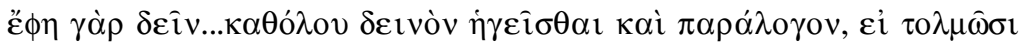

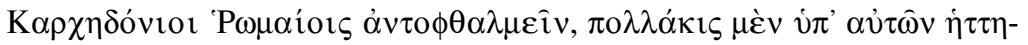

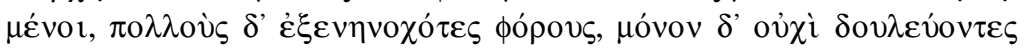

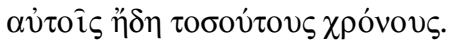

He said that they should think it altogether strange and inexplicable if Carthaginians dared to face Romans, when they had repeatedly been defeated by them, had paid much tribute, and had been all but their slaves for so long already. 


\section{MYLES LAVAN}

Scipio claims that it is folly for the Carthaginians to consider confronting men who are all but their masters. He is urging his soldiers to feel a master's contempt for Rome's 'slaves'. As in Josephus, slavery is invoked as the paradigm of domination where resistance is futile. However, this is a Roman speaking not to Rome's subjects but to his fellow Romans. In Polybius what matters is that Scipio's men remember they are masters; in Josephus it is that the Jews realise they are slaves. ${ }^{26}$ Thus, neither Thucydides nor Polybius prepares us for Titus' self-presentation as master. This is not how we expect an imperial power to represent itself in Greek historiography. The novelty of Titus' rhetoric demands some sort of interpretive response. What should we make of this Caesar who tells Rome's subjects that they are his slaves? One response would be to adapt the view of Gabba and Eckstein that Josephus is writing in the tradition of Thucydides and Polybius, a tradition of grim historical realism where empire is conventionally represented as a system maintained by terror. ${ }^{27}$ With Titus' speech, Josephus might seem to go one better than his models-constructing an imperial rhetoric that makes explicit the equation of empire and slavery that remains implicit even in Thucydides' Melian dialogue.

A familiarity with Jewish writings would offer a very different framework for making sense of the representations of the Jews as Rome's slaves. Slavery provides an important paradigm for submission to God in Jewish discourse. This can be traced back to the Exodus story, where liberation from Egypt consists in substituting service to God for service to Pharaoh. God tells Moses to say to Pharaoh, 'Let my people go, that they may serve me in the wilderness' (Exodus 7:16, repeated with variations at 8:1, 8:20, 9:1 and 9:13). The words that are used to describe service to God are the same used to describe the Israelites' subjection by the Egyptians (avodah and its cognates). In the Septuagint, this is usually translated by $\lambda \alpha \tau \rho \varepsilon v i v$ and its cognates, but at least once as $\delta$ ov $\lambda \varepsilon$ i $\alpha$ (7:16). Throughout the Hebrew Bible, the phrase 'slave of God' (ebed $Y H W H$ ) is widely used of such exceptional figures as Moses, David and the prophets, and of Israel as a whole. It is usually translated as $\pi \alpha \hat{\imath} \varsigma$ or $\delta \circ \hat{v} \lambda \circ \varsigma$

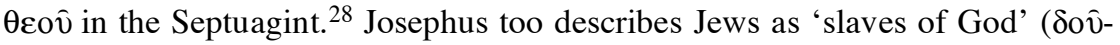
$\lambda$ or $\tau$ ov $\theta \varepsilon o \hat{v}) .{ }^{29}$ The theological importance of the slavery paradigm is particularly evident in the speech in which Josephus attempts to dissuade his fellowcaptives from suicide after their defeat in Galilee (discussed further by Jonathan Price in this volume):

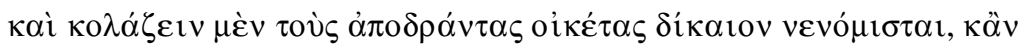

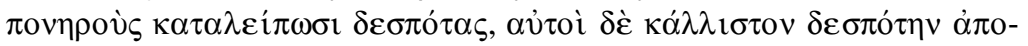

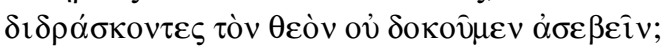

It is considered right to punish runaway slaves even if the masters they flee are wicked men. Do we think that we will not be sinning if we run away from the best of masters, God himself? 


\section{SLAVES TO ROME}

If a Jew is God's slave, Josephus argues, then a suicide is like a runaway ( $\dot{\alpha} \pi \mathrm{o}-$ $\delta \rho \alpha \dot{s})$. He expects his audience to agree that runaway slaves are always culpable, however badly they are treated. The slave who runs away from God must be the worst of all. This is the same master's ethic that Josephus and Agrippa invoke to persuade the Jews to submit to Roman rule - an ethic that leaves no space for any form of servile resistance. But here it is divine authority for which the master-slave relationship provides the paradigm. When Josephus' speakers invoke the idea of slavery in order to justify submission to Rome, this could be seen as a characteristically Jewish way of writing about authority. Far from seeming to subvert Roman rhetoric, these speakers would appear to assert the legitimacy of Roman rule by drawing parallels between submission to Rome and submission to God. (I return below to the theological questions this might raise.) Thus Titus' self-presentation as master and the extent to which he echoes the earlier language of Agrippa and Josephus reveal him as a Roman speaking a Jewish rhetoric. He knows how to represent power to a Jewish audience.

I have outlined two very different readings of Titus' self-presentation as

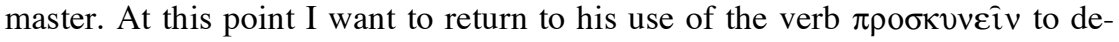
scribe submission to Rome, which I highlighted earlier in the paper:

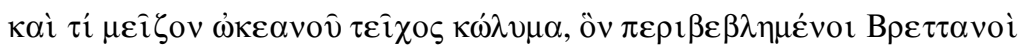

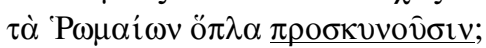

Yet what obstacle is greater than the wall of Ocean which surrounds the Britons? And they too kneel before Roman arms.

Like the language of slavery, this too is anticipated by earlier Jewish rhetoric. Agrippa in his speech repeatedly describes Rome's subjects as making proskynesis:

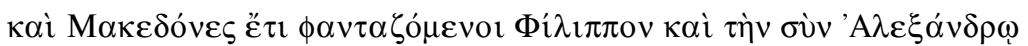

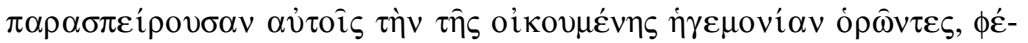

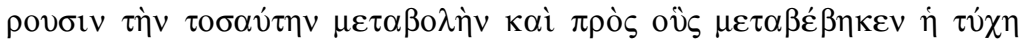

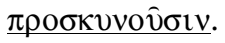

Even the Macedonians, who still conjure up images of Philip and visions of her who together with Alexander laid the seeds of a world-spanning empire for them-even they can endure so complete a reversal of fortune and kneel before those whom Fate now favours.

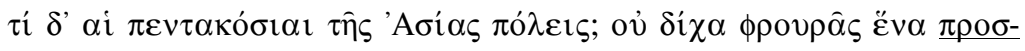

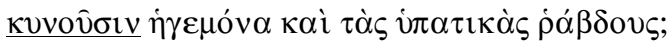




\section{MYLES LAVAN}

What of the five hundred cities of Asia? Do they not kneel before a single governor and the consular fasces, without any garrison?

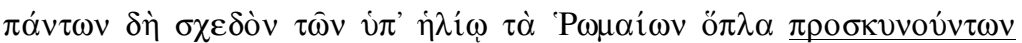
نे $\mu \varepsilon \hat{\imath} \varsigma \mu$ óvor $\pi \mathrm{o} \lambda \varepsilon \mu \eta \dot{\sigma \varepsilon \tau \varepsilon ; ~}$

When almost everyone under the sun kneels before Roman arms, will you alone make battle?

In these translations, the phrase 'kneel before' is only an attempt to convey

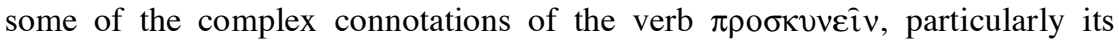
ability to slide between the spheres of the human and the divine. Proskynesis is how Greeks greeted their gods: a gesture which seems to have entailed 'blowing a kiss' and which may or may not be accompanied with kneeling or prostration. ${ }^{30}$ But the same word is also used of the apparently similar expression of deference traditionally made in Persia to superiors and particularly the Great King - a ritual which was presumed by most Greeks (rightly or wrongly) to imply that the person so venerated was a god. ${ }^{31}$ To make proskynesis to a man therefore became part of the Greek stereotype of Eastern servility.

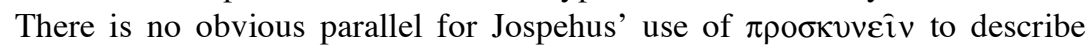
submission to Rome or any other empire. ${ }^{32}$ It is true that under the principate several foreign kings were required to perform proskynesis (adoratio) before the legionary standards. ${ }^{33}$ But these are isolated examples and there is no indication that the ritual was used in the provinces. Moreover, the objects of veneration were the legionary standards and the imperial portraits affixed to them, not 'Roman arms' (as at 2.380 and 6.331), the governor (2.366) or the Roman people (2.360). Josephus' language cannot be so easily explained away. For the reader of Greek historiography, it must be significant that the first example of a subject people making proskynesis to Rome is the Macedonians (2.360). Alexander had famously tried but failed to have himself so venerated by his Macedonian companions. ${ }^{34}$ The Romans might seem to have succeeded where even Alexander had failed - in exacting a servile, oriental form of obeisance from all their subjects. ${ }^{35}$ Here too, however, familiarity with Jewish culture would suggest a different interpretation. Whatever servile, oriental connotations $\pi \rho \circ \sigma-$ KUvยiv may have in Greek literature in general, it is a word that Jewish writers regularly use of their act of worship. ${ }^{36}$ Elsewhere in the Jewish War, the verb is only ever used of worship of the Jewish god or veneration of the temple. ${ }^{37}$ From this perspective, the use of $\pi \rho 0 \sigma \kappa v v \varepsilon i v$ might seem to be another way in which Titus uses characteristically Jewish language to imply that submission to Rome is analogous to submission to God.

It is worth pausing here to observe that the implicit parallel between Rome and God has the potential to raise an entirely separate problem for Jewish readers. ${ }^{38} \mathrm{We}$ know that much of the force of the Zealot condemnation of slavery to 


\section{SLAVES TO ROME}

Rome lay in the claim that this was incompatible with slavery to God. They invoked slavery as a paradigmatically exclusive relationship, insisting that a man can have only one master. Although Josephus plays down this religious component of the Zealot rhetoric of freedom, he does occasionally acknowledge it. ${ }^{39}$ Yet none of his speakers refutes the argument directly. By so clearly representing the Jews as slaves to Rome as well as to God, the speeches of Agrippa, Josephus and Titus seem to call attention to a controversial theological problem to which the Jewish War offers no direct answer (except insofar as it implies that slavery to Rome is ordained by God). But it is beyond the scope of this article to pursue this puzzling aspect of the work's theology.

This article has outlined the potential for two very different responses to the rhetoric of Titus' speech, depending on the extent to which expectations are formed by the conventions of Greek historiography on the one hand and knowledge of Jewish culture on the other. I do not mean to privilege one reading over the other. My point is rather to emphasise how widely interpretations of this important speech can differ depending on the literary and cultural context in which it is read. Some of Josephus' expected audience will have known little of Jewish culture apart from what they learned from the Jewish War itself. For others it must have provided the primary frame through which they made sense of Josephus' narrative. The latter would see familiar tropes in Titus' rhetoric and might recognise it as an attempt to use a characteristically Jewish rhetoric to appeal to a Jewish audience. The idea of slavery to Rome has particular resonance for those who identify themselves as slaves to God (though the implied analogy has the potential to raise other, theological problems). For the broader body of readers of Greek historiography, on the other hand, Titus' assertion that Rome's subjects are slaves and his references to proskynesis would jar with expectations of how imperial powers ought to represent themselves in political rhetoric of this kind. The incongruity of Titus' language might well appear to invite an ironic reading. The potential for such widely varying readings is particularly striking in a speech attributed to the emperor's son and the very man whose imprimatur Josephus claims to have sought and received. It nicely encapsulates the ambiguities inherent in the literary and cultural hybrid that is the Josephan project.

St John's College, Cambridge

\section{NOTES}

All references are to the Jewish War unless otherwise specified. I am grateful to the other participants of the Craven seminar for sharing their insights into Josephus. Special thanks are due to William Fitzgerald, Mary Beard, Marden Nichols, Simon Goldhill, Helen Morales and Nick Dodd for their helpful comments on this paper at various stages. 


\section{MYLES LAVAN}

1. The vast majority of the speeches of the Jewish War are delivered by Jews to Jews or Romans to Romans. The few other exceptions are much shorter than Titus' speech: 1.388-92, 2.19394, 3.400-02, 4.93-96 and 6.124-28.

2. Vit. 363, Ap. 1.50 .

3. Z. Rodgers (ed.), Making History: Josephus and Historical Method (Leiden 2007); J. Sievers and G. Lembi (eds.), Josephus and Jewish History in Flavian Rome and Beyond, Supplements to the Journal for the Study of Judaism 104 (Leiden 2005); J. Edmondson, S. Mason and J. Rives (eds.), Flavius Josephus and Flavian Rome (Oxford 2005). Equally surprising is its absence from studies of Josephus' characterisation of Titus: J.S. McLaren, 'Josephus on Titus: The Vanquished Writing About the Victor', in Sievers and Lembi, op. cit., 279-95; G.M. Paul, 'The Presentation of Titus in the Jewish War of Josephus: Two Aspects', Phoenix 47 (1993), 56-66; Z. Yavetz, 'Reflections on Titus and Josephus', GRBS 16 (1975), 411-32.

4. Vit. 358, Ap. 1.56 .

5. See especially S. Mason, 'Of Audience and Meaning: Reading Josephus' Bellum Judaicum in the Context of a Flavian Audience', in Sievers and Lembi (n.3 above), 71-100; J.J. Price, 'The Provincial Historian in Rome', ibid. 101-18; H.M. Cotton and W. Eck, 'Josephus' Roman Audience: Josephus and the Roman Elites', in Mason and Rives (n.3 above), 37-52; G.W. Bowersock, 'Foreign Elites at Rome', ibid. 53-62; T. Rajak, 'Josephus in the Diaspora', ibid. 79-97; G. Mader, Josephus and the Politics of Historiography: Apologetic and Impression Management in the Bellum Judaicum (Leiden 2000), 152-56; G. E. Sterling, Historiography and Self-Definition: Josephos, Luke-Acts and Apologetic Historiography (Leiden 1992), 297-308.

6. Mason (n.5 above).

7. Ap. 1.50-52, Vit. 361-62.

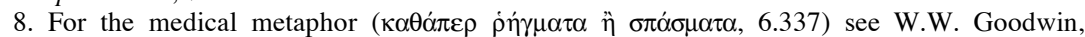
Demosthenes: On the Crown (Cambridge 1901) on Dem. De Cor. 198 (where Aeschines is like an old wound that flares up whenever Athens is in trouble), which Josephus is probably imitating here.

9. Simon: 4.272-82; Eleazer: 7.323-36, 341-88.

10. See $2.118,2.264,2.443,3.357,4.228,4.272,5.321,5.458,7.323$. The motivation of the Batavian revolt of 69-70 CE is articulated in the same terms at 7.78.

11. Ananus: 4.163-92; Jesus: 4.238-69, on which see Mader (n.5 above), 83-87 and 92-98 respectively.

12. On this speech, see T. Rajak, 'Friends, Romans, Subjects: Agrippa II's Speech in Josephus's Jewish War', in L. Alexander (ed.), Images of Empire, Journal for the Study of the Old Testament Supplement 122 (Sheffield 1991), 122-34; P. Villalba i Varneda, The Historical Method of Flavius Josephus (Leiden 1986), 92-95; E. Gabba, 'L'impero Romano nel discorso di Agrippa II', RSA 6-7 (1976-77), 189-94; H. Lindner, Die Geschichtsauffassung des Flavius Josephus im Bellum Judaicum (Leiden 1972), 21-25.

13. For the weaker sense of $\alpha \gamma \alpha \pi \alpha \omega$ ('tolerate, put up with') see the examples in LSJ s.v. III.4.

14. Discussed by Villalba i Varneda (n.12 above), 95-97, and Lindner (n.12 above), 25-33.

15. The two verbs have caused some confusion for the text of the Jewish War. At 5.366, both $\delta v \sigma \theta \alpha v \alpha \tau o v v \tau \omega \nu$ and $\delta v \sigma \theta \alpha v \alpha \tau \omega v \tau \omega v$ are attested in the manuscript tradition. Thackeray's Loeb prints $\delta v \sigma \theta \alpha v \alpha \tau o v ́ v \tau \omega v$ but translates it as if it were $\delta v \sigma \theta \alpha v \alpha \tau \omega v \tau \omega \nu$ ('longing for death'). Problems also arise at 4.27 (describing the last Romans to die in the defeat at Gamala). The manuscript tradition again preserves both $\delta v \sigma \theta \alpha v \alpha \tau o v i v \tau \omega v$ and $\delta v \sigma \theta \alpha v \alpha \tau \omega \dot{v} \tau \omega v$. This time Thackeray prints the latter but translates it as if it were the former ('struggling against death'). Ultimately the distinction will not bear too much pressure. $\delta v \sigma \theta \alpha v \alpha \tau \varepsilon \dot{\varepsilon} \omega$ is widely attested in the sense of putting up a fight against death or dying slowly and painfully. Cf. Jos. BJ 5.515 and 6.90 and, e.g., Plut. Pyrrh. 29.4, Luc. 18.5, Eum. 7.4, Cat. Min. 70.5 and Ant. 7.2 (on the dying contortions and agonies of various unfortunates). $\delta v \sigma \theta \alpha v \alpha \tau \alpha \dot{\omega} \omega$ is much rarer. In many of the attested instances it appears indistinguishable from $\delta v \sigma \theta \alpha v \alpha \tau \varepsilon \dot{\omega}$. Cf. Chrys. Stoic. 3.50 (describing an old woman just hanging on against death). The best authority for a distinctive sense ('long for death') is Titus' speech at Jos. $B J$ 6.350, but there it could conceivably be translated as 'die hard'. For my purposes the issue is moot: both senses convey the idea of a doomed struggle.

16. On the status and power of imperial slaves, see K.R. Bradley, Slavery and Society at Rome (Cambridge 1994), 69f. Cf. C. Hezser, Jewish Slavery in Antiquity (Oxford 2005), 100-04, on the similar situation of the patriarchs' slaves in Jewish culture.

17. S. Mason, 'Figured Speech and Irony in T. Flavius Josephus', in Mason and Rives (n.3 above), 243-88, at 271 .

18. Rajak (n.12 above), esp. 132. 


\section{SLAVES TO ROME}

19. Various aspects of the rhetoric of freedom and slavery in the $B J$ are discussed by Mader (n.5 above), 83-87 and 92-100, and by J. Byron, Slavery Metaphors in Early Judaism and Pauline Christianity: A Traditio-Historical and Exegetical Examination, Wissenschaftliche Untersuchungen zum neuen Testament 2. Reihe 162 (Tübingen 2003), 81-95. It is telling that Mader, who is interested in Josephus' use of a Thucydidean model, discusses the speeches of Ananus and Jesus, which contradict the rebel claim that Rome's subjects are her slaves (as a reader of Thucydides would expect) but not those of Agrippa, Josephus or Titus which embrace it.

20. See Hezser (n.16 above) for a recent synthesis of the evidence for slavery in Jewish culture in the classical period, arguing for considerable continuity with practices of slavery in the broader Greco-Roman world. The rhetoric of the Josephan speeches raises broader questions about how slavery was used to think about other power relations in Roman culture and how Roman rule was represented to Rome's provincial subjects. These are discussed in detail in my forthcoming Cambridge doctoral dissertation (Rome and the Provinces: Slavery, Patronage and Other Paradigms for Empire).

21. See Mader (n.5 above) and A.M. Eckstein, 'Josephus and Polybius: A Reconsideration', ClAnt 9 (1990), 175-208, on Josephus' use of Thucydides and Polybius respectively.

22. K. Raaflaub, The Discovery of Freedom (Chicago 2004; orig. publ. Munich 1985 as Die Entdeckung der Freiheit), 129. Raaflaub offers the best discussion of empire and slavery in Thucydides (see 120-30)

23. Phrynichus addressing an Athenian council of war at 8.48.5.

24. Melians describe Athens' subjects as slaves: Thuc. 5. 86, 92, 100. Athenians prefer vंń-

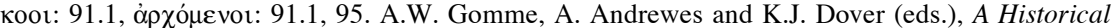
Commentary on Thucydides Vol IV (Oxford 1970), 163f., argue that the Athenians assimilate the relationship between an imperial power and its subjects to that of a master and slave. P. Low, 'Looking for the Language of Athenian Imperialism', JHS 125 (2005), 93-111, at 94, describes the Athenians as speaking to 'prospective slaves in the imperial machine'. But it is nevertheless significant that the Athenians avoid making the comparison explicit.

25. See e.g. the speech of Philopoemen (Pol. 24.13)

26. Indeed, Josephus' Titus hardly ever describes the Jews as slaves in his speeches to Roman audiences. The language of slavery features only once (6.42) in Titus' four speeches to his troops (3.472-84, 3.494-96, 6.33-53 and 7.6-12). It does not occur at all in Vespasian's two speeches to Roman audiences (4.40-48 and 4.368-76).

27. Gabba (n.12 above); Eckstein (n.21 above).

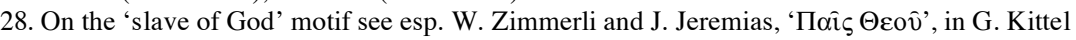
(ed.), Theological Dictionary of the New Testament (Grand Rapids 1964-76), v.654-717; Hezser (n.16 above), 327-32, on the Hebrew Bible; Byron (n.19 above) on the Septuagint and Hellenistic texts. Mediated by Paul, this Jewish trope develops into the Christian servus Christi. See D.B. Martin, Slavery and Salvation (New Haven 1990); Byron (n.19 above); I.A.H. Combes, The Metaphor of Slavery in the Writings of the Early Church: From the New Testament to the Beginning of the Fifth Century, Journal for the Study of the Old Testament Supplement 156 (Sheffield 1998).

29. AJ 11.90 and 101. See J.G. Gibbs and L.H. Feldman, 'Josephus' Vocabulary of Slavery', Jewish Quarterly Review 76 (1986), 306-08, for other examples of the language of slavery applied to a religious context.

30. See esp. B.M. Marti, 'Proskynesis and Adorare', Language (1936), 272-82, correcting H. Bolkestein, Theophrastos' Charakter der Deisidaimonia als religionsgeschichtliche Urkunde, Religiongeschichtliche Versuche und Vorarbeitung 21.2 (Giessen 1929).

31. Greek responses to Persian proskynesis include Xen. Anab. 3.2.13, Isoc. Pan. 151, Arist. Rhet. 1367a27, Arr. Anab. 4.9.9-12.5. For the Persian practice, see R.N. Frye, 'Gestures of Deference to Royalty in Ancient Iran', IA 9 (1972), 102-07, and P.A. Brunt, Arrian (Cambridge MA \& London 1976), i.538f.

32. In Herodotus, Polybius and Diodorus Siculus, $\pi \rho \circ \sigma \kappa v v \varepsilon i v$ is only ever used of the worship of gods or of self-abasement before individuals, never for the relationship of one people to another. It does not occur at all in Thucydides or Dionysius of Halicarnassus.

33. Artabanus in 37 CE (Suet. Gaius 14.3. Vit. 2.4), Zorsines in 49 (Tac. Ann. 12.17.2), unnamed German kings under Nero (ILS 986). On the legionary standards and the imperial portraits they bore, see C. Ando, Imperial Ideology and Provincial Loyalty in the Roman Empire (Berkeley 2000), 259-69. The adoption of proskynesis (adoratio) into imperial ceremonial comes later. See A. Alföldi, 'Die Ausgestaltung des monarchischen Zeremoniells am römischen Kaiserhofe', $M D A I(R)$ 49 (1934), 1-118. 


\section{MYLES LAVAN}

34. For the famous story see Plut. Al. 54, Arr. Anab. 4.9.9-12.5, Curt. 8.5.6-24, etc.

35. Josephus might also be seen as anticipating the Second Sophistic trope of describing Rome as a new Persian empire, discussed by S.C.R. Swain, Hellenism and Empire: Language, Classicism and Power in the Greek World (Oxford 1996), 176f., and E.L. Bowie, 'The Greeks and Their Past in the Second Sophistic' in M. Finley (ed.), Studies in Ancient Society (London 1974), 166-209 (= $P \& P 46$ [1970], 3-41), at 201 n.95.

36. It occurs 124 times in the Septuagint, 37 times in Philo and 76 times in Josephus himselfalmost exclusively of worshipping God.

37. See $1.73,2.341,2.414,2.444,4.262,5.99,5.381$.

38. The question of the interaction between models of divine and temporal authority has also been raised recently by Tessa Rajak, who compares the angry tyrant and the angry God. See T. Rajak, 'The Angry Tyrant', in T. Rajak and S. Pearce (eds.), Jewish Perspectives on Hellenistic Rulers (Berkeley 2007), 110-27, at 116f.

39. Mader (n.5 above), 12-17 and 28 n.20, discusses how Josephus collapses the Zealot objection to enslavement into a purely political sentiment. But Josephus does allude to its theological aspect (the incompatibility of slavery to Rome with slavery to God) on two occasions: 2.118 and 7.323. On the Zealots' theology, see M. Hadas-Lebel, Jerusalem Against Rome (Leuven 2006; orig. publ. Paris 1990 as Jérusalem contre Rome ), 439ff.; Byron (n.19 above), 82-95. 